\title{
Constitutional Identity and the Identity of the People: The Constitutional Conceptualization of Non-Status and Off-Reserve Indigenous Populations in Canada
}

\author{
Jula Hughes ${ }^{*}$
}

\begin{abstract}
This article focuses on the issue of the relationship between constitutional recognition and constitutional imposition of identity. The Canadian state in its constitutional document describes itself as a liberal democracy governing a pluralist society. It also recognizes Aboriginal rights as constitutive. The first two elements have met with considerable success in terms of aligning state and citizen identity. This suggests that neutral constitutional identities or identities that respect individual diversity can be imposed successfully through the democratic process. However, these are not effective in meeting decolonizing objectives, which must instead be pursued through respecting Indigenous self-governance.
\end{abstract}

Keywords: Indigeneity, Aboriginal rights, UNDRIP, legal pluralism

\section{INTRODUCTION: FROM LIBERALISM TO LEGAL PLURALISM}

In a recent article on constitutional identity, Richard Albert observed that 'constituent power theory refers to the people as an amorphous whole, with neither quantification nor qualification of who the people are'. ${ }^{1}$ Despite lacking an introductory 'We, the People', the Canadian constitution may appear to be doing just that. In its first section, the Canadian Charter of Rights and Freedoms (the 'Charter') describes Canada as a 'free and democratic society' ${ }^{2}$ without any specification as to who the people in this society may be. The use of broad inclusive language is consistent with classical liberal theory, which contemplates the constitutional subject of 'the People' in neutral and universalist terms.

Yet, a review of later parts of the Charter reveals a more textured, pluralist approach that is layered over the universalist beginning. In the equality rights guarantee, the Charter speaks inter alia to the racial, national, ethnic, religious, gender and bodily diversity of the People. Other parts address linguistic and cultural diversity as constitutive of Canadian society. The pluralist idea that a single free and democratic society, the constitutional identity of the Canadian state, can accommodate within itself a population of individuals with multi-dimensional diversities allows Canadians of many political stripes and backgrounds to see themselves in the constitutional mirror.

This capacity of the constitution to reflect back an image of state identity that invites people to self-identify with the state is a powerful mechanism that promotes identity alignment between the individual and the state. When the constitutional text, and one might argue, public discourse, fails to engage people in this way, there appears to be a widespread sense of being left out. The present idea has animated pluralist conceptions of constitutional law and encouraged legislators to respond to the demands of historically disadvantaged or excluded groups for inclusion through textual constitutional recognition. This has

\footnotetext{
* Professor and Dean, Bora Laskin Faculty of Law, Lakehead University (Canada), dean.law@, lakeheadu.ca.

1 Albert (2018) 6.

2 Canadian Charter of Rights and Freedoms, Constitution Act, 1982, being Schedule B to the Canada Act, 1982 c. 11 (U.K.).
} 
resulted in the inclusion of express language in some constitutional texts of the $20^{\text {th }}$ century including the Canadian Charter. By contrast, the universalist language of the equality clause in the $14^{\text {th }}$ Amendment of the US Constitution could be considered as an example of the classical liberal position.

The pluralist innovation of textual recognition of specific identities has responded to concerns of exclusion for equality-seeking groups but has been seen as going too far for some and not far enough for others. What used to be thought of as remedial constitutional language addressing past exclusion is now being mobilized for the constitutional recognition for members of privileged majorities. Ran Hirschl, in a very useful article from a comparative and international perspective, described this trend as a kind of resistance to global (universalist and/or pluralist) constitutional convergence. ${ }^{3}$ He suggested that the resistance is often motivated by political populism and that it asserts majoritarianism, parochialism and national parliamentary sovereignty as key values.

At the same time as a populist backlash reaching across national boundaries has contended that constitutional recognition of diverse minority identities has gone too far, the pluralist project has also not been entirely effective in winning the hearts and minds of ome of Canada's most marginalized communities. A prominent example is the relationship of the Canadian state with people who identify as Indigenous. Despite active participation of Indigenous leaders in the constitutional conferences of the 1980s and the inclusion of textual references to Aboriginal rights in Section 35 of the Constitution Act, 1982, Indigenous people, community leaders, activists and academics describe a deep fissure between self-identity and the Canadian legal order as expressed in the constitution. ${ }^{4}$

This paper tilts away from majoritarian claims to textual recognition which dominate the current discussion of constitutional identity. It instead addresses why textual constitutional recognition may be inadequate and what modes of constitutional recognition may address the inadequacy.

Specifically, the article explores why the express textual constitutional recognition of Indigenous Peoples in the Canadian constitutional text has fallen short of performing the task of effective constitutional recognition is explored. How is it that a litany of court cases, political action, learned and community activist writing has not resulted in a constitutional text and discourse that gives many Indigenous people even a glimpse of themselves in the constitutional mirror? In asking this question, there is no intention to advance a normative argument that Indigenous people 'should' identify themselves with the Canadian state. ${ }^{5}$ Rather, exploring the question may help to think through the relationship between constitutional recognition and constitutional imposition of identity. It may also help us understand better the tension between recognition and self-determination experienced by Indigenous Peoples in their relationship with the Canadian state.

In a post-colonial society, the goal of a 'workable constitutional identity' may ultimately be entirely elusive. At the bare minimum, it is clear that constitutional recognition for Indigenous Peoples requires something different than either state imposition of a majoritarian vision or state recognition of pluralist or multicultural individual identities.

\footnotetext{
${ }^{3}$ Hirschl (2018) 1.

${ }^{4}$ Green (2017) 175., Coulthard (2007) 437.

5 Coulthard (2007) 6.

6 Rosenfeld (2009) 132.
} 
Neither recognition regimes grounded in universalist or pluralist constitutional theories based on the 'sovereignty of a people' are adequate to the task of addressing recognition demands by Indigenous Peoples.

These theories fail because, as Larry Chartrand has argued, neither democratic nor sovereignty-based recognition can legitimate the state for Indigenous Peoples. ${ }^{7}$ An underlying reason for this lack of legitimacy is that the state misses two essential elements that are necessary for the social contract to function: the origin of the social contract must be imagined to be ultimately voluntary and it must be lost in the mists of history. Neither is true for Indigenous Peoples as the social contract is demonstrably neither voluntary nor ahistorical. Instead, it was imposed violently and is remembered as a specific historical event. It is important not to misstate this difference between the liberal master narrative and the constitutional situation of Indigenous Peoples.

The issue is not that an illegal act cannot give rise to a legitimate legal order. The rise of a constitutional order from despotic ashes is more common than not and many liberal democracies found their existence on violent overthrow. Instead, the issue is the ongoing legal and constitutional subordination of Indigenous Peoples in the context of an otherwise liberal democracy - the transition from a colonial government to a democratic one was not sufficiently radical to accomplish what Michel Rosenfeld has described as one of two essential factors for political transformation:

'a move away from old habits and obsolete self-images for purposes of evolution towards a new collective self-identity suited to the emergent political and institutional order.'8

In characterizing this historical and political situation as the impossibility of liberating constitutional identity renders problematic the long quest of Indigenous activists, particularly of Indigenous women, for constitutional and legal recognition. ${ }^{9}$

It is argued that tolerance for and indeed support of, a different kind of pluralism is needed. A form of legal pluralism is required where the state acknowledges and defers to Indigenous governance institutions as imbued with their own inherent power of constitutional recognition. Canada has partially moved in this direction when First Nations communities were recognized as having the power to determine their own membership. ${ }^{10}$ It is now moving further in this direction in a consultation exercise directed by the Canadian Senate in response to a decision by the Quebec Superior Court in Descheneaux.

This path is consistent with the ancient and persistent claim of First Peoples to selfdetermination and the more recent assertion of rights of Indigenous Peoples under UNDRIP. ${ }^{11}$ Its full implementation opens up the possibility of a new, legally pluralistic phase in Canadian constitutional lawmaking.

This paper proceeds in three parts. The first part situates the issue of recognition powers in Canadian constitutional law. From the constitutional texts and key decisions of the Supreme Court of Canada from Powley to Daniels and Descheneaux, the first part

7 Chartrand (2016) 167.

8 Rosenfeld (2009) 130.

9 Green (2017).

10 Bill C-31: An Act to Amend the Indian Act (S.C. 1985, c.27).

11 UN General Assembly, United Nations Declaration on the Rights of Indigenous Peoples: resolution adopted by the General Assembly, 2 October 2007, A/RES/61/295. 
demonstrates that Canadian law has circumscribed but not resolved the issue of recognition for Indigenous Peoples.

The second part seeks out entities that have the potential or actual capacity to perform the function of constitutional recognition for Indigenous Peoples. It describes the existing landscape of Indigenous self-governance and representational claims and considers in particular organizations that seek to represent Indigenous people who are not recognized by the state, in particular the Congress of Aboriginal Peoples.

The third part provides a case study of membership recognition of CAP affiliated Native Councils in the Maritime provinces. The case study sought to determine to what extent the processes used by Native Councils accord with the demands of the constitutional jurisprudence. It demonstrates the capacity of one set of self-governance organizations to address the recognition issue left unresolved by Canadian constitutional law. The paper concludes that legally pluralistic approaches can be effective as long as state law respects Indigenous self-governance organizations as communities of recognition.

\section{THE INADEQUACY OF TEXTUAL RECOGNITION}

The Canadian constitutional texts speak to Canada's Indigenous populations in different places. Three of these are very well known including references in the federal power provisions of the Constitution Act, 1867, in the Canadian Charter of Rights and Freedoms and the Aboriginal Rights section of the Constitution Act, 1982.

The Constitution Act, 1867 establishes in Section 91(24) the power to legislate with respect to 'Indians and land reserved for Indians'. Section 25 of the Charter safeguards Aboriginal rights from abrogation or derogation through Charter claims. Finally, Section 35 of the Constitution Act, 1982 constitutionally entrenches existing Aboriginal rights. It also defines 'Aboriginal' to include 'Indian, Inuit and Métis Peoples'; permits for the development of new rights through treaty and protects gender equality with respect to these rights. Less well-known places in the constitutionally relevant texts can be found in constitutional documents from the 1930s that sought to put Western provinces on the same footing as the founding Eastern provinces, generally referred to as the Natural Resources Transfer Agreements. ${ }^{12}$ Importantly, these agreements imposed on the provinces obligations incurred by the federal Crown vis-á-vis Indigenous populations. ${ }^{13}$ The Supreme Court agreed with the federal government's position and held that, under paragraph 2 of the NRTAs, the provinces had agreed to undertake all outstanding obligations owed by the federal government prior to the NRTAs. ${ }^{14}$

None of these textual references in the constitutional Acts, be they top-of-mind or more obscure, specify either a process for identifying who is an Aboriginal person or community, or for that matter a substantive definition. ${ }^{15}$ And yet, some process is necessary

12 The Supreme Court of Canada held in $R v$ Blais, [2003] 2 SCR 236, 2003 SCC 44 that hunting rights guaranteed to 'Indians' under the NRTA did not extend to the Métis. In Daniels $v$ Canada (Indian Affairs and Northern Development), [2016] 1 SCR 99, 2016 SCC 12, the Supreme Court of Canada distinguished Blais on the basis that the interpretation of a constitutional agreement attracted different interpretive principles (though the Court did not identify what they might be).

13 Reference re Refunds of Dues re Timbre Permits, [1933] SCR 616, aff'd In re Refund of Dues Paid Under s. 4769 of the Timber Regulations in Manitoba, British Columbia, Saskatchewan and Alberta, [1935] AC 184 (PC) See also: O'Byme (2006) 215.

14 O'Byme (2006) 229.

15 McNeil (1982) 255. 
because identity, including Indigenous identity, is a complex matter; and being included or being excluded has important legal consequences. ${ }^{16}$

Canadian state law has adopted two approaches: legislation supported by administrative action; and jurisprudential development of criteria. The legislative approach is limited to Indigenous populations falling under the Indian Act. For individual recognition, the key administrative action supporting the Indian Act is the maintenance of the Indian Register, a list of status Indians and their band membership, if any. The jurisprudential approach has been used categorically/collectively to answer questions about the scope of federal jurisdiction over Inuit, ${ }^{17}$ non-status Indians, ${ }^{18}$ and Métis people. ${ }^{19}$ It has also been used individually to determine whether a particular person is a rights-holder. None of the state law delves into the identity of people as members of the many different nations; ${ }^{20}$ in the territories where the research for this paper was conducted, people identify as Mi'kmaq, Wolastoqey (or Maliseet), Passamaquoddy and collectively as Wabanaki. They may also describe themselves as Indigenous, Aboriginal or Native in their relationship with settler society but these labels tend not to be used as intra-group relational terms.

There is no single Aboriginal nation in Canada, nor are there three nations that self-identify in the terms of the expanded definition of Section 35. As a result, the constitutional question whether an individual is Aboriginal for the purposes of Section 35 or an 'Indian' for the purposes of Section 91(24) is not answered by looking to a single collective (national or otherwise) of Aboriginal people but is instead analyzed by looking to other collectivities at the community or tribal/national level.

The constitutional text does not provide any detail on criteria or processes of recognition and is thus analogous to the constitutional regime of Canadian citizenship. In granting democratic rights to Canadian citizens in Section 3 of the Charter, the constitutional text is silent on the criteria for Canadian citizenship - it also does not elaborate on the procedures for acquiring or asserting citizenship. These details can, however, be found in ordinary legislation, viz. the Citizenship Act.

The only ordinary legislation dealing with Indigenous identity is the Indian Act. Even on the face of the constitutional text, it is apparent that this Act does not match the categories of rights holders in Section 35 (the Act does not apply to Métis or Inuit). Constitutional case law further clarifies that federal jurisdiction over 'Indians' in Section 91(24) is not limited to people with status under the Indian Act. Thus, the Act fails to provide the kind of comprehensive substantive and procedural regime found in the Citizenship Act. It is underinclusive.

The demographic realities further highlight the under-inclusive nature of the statutory scheme of recognition. The Canadian census regularly reveals that many more people identify as Aboriginal than are recognized by the state under the Act. A significant majority of people who self-identify as Aboriginal in Canada do not reside in a First Nation community (reserve community). This includes First Nations people residing off reserve, Métis and Inuit. Latest census data indicates that there were 744,855 First Nations people with registered or treaty Indian status in 2016, accounting for just over three-quarters $(76.2 \%)$ of the First Nations population. There is a strong trend towards urbanization.

16 Grammond (2009).

17 Reference as to whether "Indians" includes in Section 91 (24) of the B.N.A. Act includes Eskimo in habitants of the Province of Quebec, [1939] S.C.R. 104.

18 Daniels v Canada (Indian Affairs and Northern Development), [2016] 1 SCR 99, 2016 SCC.

19 Daniels v Canada (Indian Affairs and Northern Development), [2016] 1 SCR 99, 2016 SCC.

20 Patterson (2006). Swachuk (2001) 73. 
Among the 744,855 First Nations people with registered or treaty Indian status, $44.2 \%$ lived on reserve in 2016, while the rest of the population lived off reserve. There is also very significant growth in the non-status population. The $23.8 \%$ of First Nations which did not have registered Indian status, has grown by $75.1 \%$ since 2006 to 232,375 people in 2016 . This is not to suggest that every single person self-identifying in the census and/or seeking recognition through a non-status organization should necessarily be so recognized, nor that all of these organizations are appropriately thought of as communities of recognition. This merely points out that there is a significant gap between self-identification and state recognition. Beyond claiming Indigenous identity, many more people self-describe as having an Indigenous ancestry.

Further, census data and data maintained under the Indian Register do not match up and there are some doubts about both sets of numbers. For example, the census identifies 744,855 status Indians compared to 970,562 status Indians registered in the Indian Register.

The discrepancy supports assumptions in Indigenous circles that the census figures are under-reporting. Indigenous experts believe that this is because of the significant risk of facing racism and adverse treatment. Sawchuk notes that the very process of claiming Aboriginal identity is full of ironies caused by the implicit attorning to the state law mechanisms of recognition. ${ }^{21}$ Conversely, being perceived as Aboriginal is often a matter of choice. Many Aboriginal people, particularly in Eastern Canada, are not perceived as Aboriginal by mainstream society unless they make a point of self-identification, effectively coming out as Indigenous. ${ }^{22}$ Thus, in the absence of self-identification, many Aboriginal folk are invisible to the mainstream in their constitutional identity.

A particularly striking example of this constitutional invisibility can be found in Newfoundland. When Newfoundland joined Confederation in 1949, the Terms of Union were silent on any Indigenous population. Consequently, the Indian Act was not applied to the new province of Newfoundland and no reserves were set aside. ${ }^{23}$ Subsequent agreements recognized and addressed benefits for Inuit and Innu populations of Southern Labrador, while Mi'kmaq populations continued to be ignored. As is often the case in Canadian Indigenous-settler relations, the historical record for the reasons of addressing Indigenous issues in this manner are mixed. Some aspects of the records seem to suggest deliberate neglect, while others entertain questions of detrimental effects of depriving native Newfoundlanders of previously enjoyed rights and privileges as full citizens of that country in the new context as a Canadian province.

All sides were unsure of the size of the population but estimated them to be in the hundreds. The Federation of Newfoundland Indians was founded in order to give voice to this Indigenous population and in 1989 the Federation filed suit in Federal Court seeking to assert a constitutional equality right to recognition under s. 15 of the Charter. This matter was never heard on the merits but an agreement was reached to permit Newfoundland Mi'kmaq people to register. Prior to registration, estimates ran in the order of 10,000 individuals who might be eligible. Registration exceeded 100,000. About 80,000 registrations were denied and in a second cut, number of individuals who had previously been given Indian Act status had that status removed. ${ }^{24}$

${ }^{21}$ Sawchuk (2001).

22 Thank you to Janelle Marchand for our discussion on the similarities between coming out as Indigenous and coming out as LGTBQ.

23 MacKenzie (2010) 1719.

24 Thomson, link 3. 
As a practical matter, state recognition is not entirely limited to Indian status, as the Canadian government has long recognized other Indigenous populations in addition to status Indians. The jurisdictional distribution and rights associated with Indigenous status other than status under the Indian Act remained, however poorly understood.

Furthermore, state recognition has endemic discriminatory features. There is a long history of Canadian state law describing and recognizing Indigenous individuals and communities in an under-inclusive, discriminatory and divisive manner. ${ }^{25}$ These include a long history of gender discrimination, family status discrimination, ${ }^{26}$ age discrimination, ${ }^{27}$ and discrimination on the basis of occupation. ${ }^{28}$ There have been multiple legislative attempts to address the gender discriminatory features of the Indian Act, including Bills C-31, C-3 and most recently S-3 in response to extensive rights litigation including litigation at the level of the United Nations. ${ }^{29}$ The latest legislative round was most revealing in that the government opposed an amendment that worked to truly eliminate gender discrimination on the basis that that would result in too many people of undisputed Aboriginal ancestry being recognized as status Indians under the Act. Gender discrimination also resulted in over-inclusiveness as non-Indigenous women who married Indigenous men acquired status and were able to pass status on to their children.

Given the parsimony and misalignments of the constitutional text and the absence of comprehensive statutory definitions, there is a significant body of case law that has attempted to address these issues. The Supreme Court of Canada first articulated the legal test for Aboriginal identity for purposes of determining whether someone was an Aboriginal rights-holder under s. 35 in 2003 in the Powley decision. ${ }^{30}$ The test is a close analogue to the approach taken by Australian legislation and jurisprudence. ${ }^{31}$ It includes three elements: self-identification, ancestral connection and community recognition. Much has been written about the first two elements while the third element has received less attention. ${ }^{32}$ Very briefly, the first element, self-identification is a primarily individual matter. Courts are looking to the individual to self-identify as for example Mi'kmaq or Cree, as Métis or Inuit. Problems arise with some frequency related to the timing and lived experience of selfidentification but the criterion is not conceptually difficult.

Ancestral connection and community recognition are more complex. This is in part because they overlap - ancestral connection is inevitably a factor in community recognition and is sometimes the controlling factor. It is also complex from an evidentiary perspective because ancestral connection requires a recognized ancestor. Further, it is often entangled with essentialist rules regarding blood quantum and complicated by varying practices of custom adoption, patterns of intermarriage and territorial displacement, colonial patrilineality and mixed approaches to genealogy in Indigenous legal systems.

25 Hughes - Stewart (2015) 263.

26 Gehl v Canada (Attorney General), 2017 ONCA 319.

27 An example is the 1951 cut-off rule.

${ }^{28}$ Section 99 of the Indian Act dealing with enfranchisement of university graduates and professional qualifications (1880 amendment).

29 Sandra Lovelace v Canada, Communication No. 24/1977: Canada 30/07/81, UN Doc. CCPR/ C/13/D/24/1977 prompted Bill C-31.

30 R v Powley, [2003] 2 SCR 207.

31 Gardiner-Garden (2003).

32 Sawchuk (2001), Grammond (2009), de Costa (2014) 55. 
This paper focuses on the least explored aspect of the third element, community acceptance is focused on and interrogate the criteria and processes that might lead to state law recognition of a community as a community with the power of recognition. The Powley test presupposes and the Court in Powley accepts that there is a recognized community that has the power of recognition and the capacity to exercise this power. Yet, what constitutes a community with the power of recognition is contested and unclear. There are no legislative criteria for recognizing a community of recognition and populations outside of the Indian Act regime are poorly understood. ${ }^{33}$ There is no comprehensive ethnographical study of non-status and off-reserve populations. ${ }^{34}$ The jurisprudence is also underdeveloped. In Powley, the Supreme Court of Canada noted the importance of community self-definition as well as the establishment of standardized and objectively verifiable membership criteria. The Court also linked the issue of identity to the purpose of Métis rights under Section 35, which it held to be 'to recognize and affirm the rights of the Métis held by virtue of their direct relationship to this country's original inhabitants and by virtue of the continuity between their customs and traditions and those of their Métis predecessors' (at para 29). There are other cases where the Court has taken a less purely historical view of the purpose of Section 35 rights, which may also be relevant here.

Thus, the Court has accepted that communities can and should self-define and has encouraged standardized and verifiable membership criteria and processes. At the same time, the Court has cautioned Métis organizations that their membership processes may not be determinative, depending on the requirements and the role of the organization in the community

Membership in a Métis political organization may be relevant to the question of community acceptance but it is not sufficient in the absence of a contextual understanding of the membership requirements of the organization and its role in the Métis community. ${ }^{35}$

It is not entirely clear what kind of contextual understanding would allow a court to place reliance on the membership process of an Indigenous political organization. It is even less obvious how a court would go about evaluating the role of an organization in a community. Even the unit of analysis, community, is problematic. It appears to envision a village-by-village recognition process, which may be close to or very far removed from a particular Indigenous legal tradition and practice. It may also create barriers for non-status Indigenous people whose community is political and does not have a clear geographical boundary.

The Supreme Court of Canada had the opportunity to provide more guidance in the Daniels case. The Court recognized that Métis and non-status people were to be considered 'Indians' for the purposes of federal jurisdiction pursuant to Section 91(24) of the Constitution Act, 1867 but in a sparse decision retreated to the view that individual identity had to be determined on a case-by-case basis without further elaboration. ${ }^{36}$ To make matters

33 Grammond - Groulx (2012) 33.

34 We conducted a study with respect to four distinct populations in New Brunswick that are represented by the New Brunswick Aboriginal Peoples Council, the provincial affiliate of CAP. Hughes - Stewart - Plummer (2015).

$35 \mathrm{R}$ v Powley, para 33.

36 Daniels v Canada (Indian Affairs and Northern Development), [2016] 1 SCR 99, 2016 SCC, para 47. 
more complex, the Court also noted in Daniels that the community acceptance test was inapplicable to the determination of jurisdiction for purposes of Section 91(24) of the Constitution Act, 1867. This was because the Court was concerned that the application of a community acceptance test was liable to exclude individuals who were no longer accepted by their communities as a result of state action including the removal of Indigenous children from their communities in the Indian Residential School system. ${ }^{37}$ It is not obvious why this history of state-sponsored exclusion would not be equally relevant to the scope of Aboriginal rights or the recognition of political communities organizing non-status people.

The latest iteration of grappling with the inadequacies of the statutory recognition scheme was prompted by the decision of the Quebec Superior Court in Descheneaux v Canada in August of 2015. The Court declared key provisions of the Indian Act inoperative because they unjustifiably violated equality rights under the Charter. This followed the amendments to the Indian Act in Bill C-31 in 1985 and C-3 in 2011, both of which had responded to earlier judicial findings of gender discrimination with respect to eligibility for Indian registration. Descheneaux is the progeny of earlier decisions in the Lovelace and McIver cases in the most literal sense, as it traces the intergenerational effects of sex discrimination of these earlier cases to the descendants of the male and female lines.

The political response to Descheneaux also initially followed an established pattern. ${ }^{38}$ The government proposed to amend the Indian Act to respond to the particularized issues of the court case while also indicating an intention to maintain other discriminatory elements of the regime in order to avoid recognition of a large number of descendants who were similarly but not identically affected by other gender discriminatory aspects of the Indian Act recognition regime.

However, the Members of the Standing Senate Committee on Aboriginal Peoples insisted that a more fulsome reform be initiated and that the Indian Act be purged of its gender discriminatory aspects once and for all. In Bill S-3, the senators forced the government's hand by introducing a broader amendment the purpose of which was 'to entitle to registration (...) those persons who were previously not entitled to registration (...) as a result of the preferential treatment accorded to Indian men over Indian women born prior to April 17, 1985 and to patrilineal descendants over matrilineal descendants born prior to April 17, 1985.

The Indian Act was amended in December of 2017 and Parliament included in the law an elaborate, two-phased consultation process on issues regarding Indian registration, band membership and First Nation citizenship. The first stage, scheduled for May of 2018, saw a report on the outcome of a co-created consultation process. The second stage sets out an ambitious one-year timeline for reporting back results in June of 2019. The third stage, scheduled for the end of 2020 will evaluate whether S-3 was successful in eliminating gender discrimination from the Indian Act. Part of the consultation will consider 'the continued federal government role in determining Indian status and band membership'. This promises a shift in Canadian law towards greater respect for Indigenous selfgovernance.

Further support for Indigenous self-governance and state law toleration comes from emergent legal standards in international law as well as important Canadian academic commentary. The United Nations Declaration on the Rights of Indigenous Peoples supports

37 Daniels v Canada (Indian Affairs and Northern Development), [2016] 1 SCR 99, 2016 SCC, para 49.

38 Cossette, link 1. 
Indigenous claims to self-determination of identity, firmly locating the power of recognition with Indigenous jurisdiction. Article 33 of UNDRIP acknowledges a right of Indigenous Peoples to determine their own identity or membership. Specifically, it provides:

1. Indigenous peoples have the right to determine their own identity or membership in accordance with their customs and traditions. This does not impair the right of indigenous individuals to obtain citizenship of the States in which they live.

Article 33 goes further and recognizes not merely jurisdiction over individual recognition but also a right to collective self-determination of structures and institutions.

2. Indigenous peoples have the right to determine the structures and to select the membership of their institutions in accordance with their own procedures.

It is the collective of a People that has the right to determine the structures and institutions that operationalize self-governance. Groups have a right of recognition and individuals' rights to membership are contingent on that recognition and yet the group is constituted by the people recognized. The idea animating these guarantees is that settler governments may not usurp the power of recognition nor do they have jurisdiction over the choice of institutions and structures or Indigenous procedures associated with their establishment or maintenance.

Claims for self-governance regarding membership have met with support from some important settler scholars in the area as well. ${ }^{39}$ For example, Prof. Grammond (now Justice Grammond) in his seminal text on membership and recognition has convincingly argued in favour of autonomy of representative minority (Indigenous) institutions.

Those institutions are in a better position than the state to define what constitutes the ethnicity of the group. Moreover, while the state may adopt membership criteria that result in the oppression of the minority (for example, the criteria of the old Indian Act), a minority is less likely to do so. The right of self-determination in international law, as well as its domestic manifestations (such as the aboriginal right to self-government), also militate for the recognition of the power of self-definition for minorities. ${ }^{40}$

The various difficulties evident in state law, including the long history of gender discrimination under the Indian Act as well as the Minister's plea for delay in response to Bill S-3 may suggest to some that the issue is complex or even intractable. Contrary to this perception, it can be shown that the essential elements for a functioning and nondiscriminatory regime have long been known and, importantly, practiced by Aboriginal organizations representing Indigenous populations ${ }^{41}$ outside of or beyond the Indian Act. These practices are born of the universal assertion of jurisdiction over membership, identity and recognition by Indigenous Peoples in Canada and they align with the overall trend in Canadian law to increase self-governance over membership.

39 Green (2001) 715, Sayers et al. (2001); Napoleon (2009) 233.

40 Grammond (2009) 190.

${ }^{41}$ I am using the term populations rather than Peoples not to detract from the recognition of Indigenous Peoples as Peoples, but instead to acknowledge the diasporic nature of many Indigenous people living in Canada off-reserve and/or outside of their traditional territories. 


\section{ABORIGINAL GOVERNMENTAL BODIES}

In this context, it is important to at least briefly recall the current institutional landscape of Aboriginal governments and organizations in Canada. There are broadly speaking three sets of players in the Canadian political landscape: First Nations (Indian Act) communities, tribal organizations and national Aboriginal organizations. First Nations communities have express power of recognition to the extent that they have the power to create their own membership codes. ${ }^{42}$ They are limited in their power of recognition by being subject to the federal power of recognition exercised under Section 6 of the Indian Act. Thus, the power of recognition for communities regulated by the Indian Act is split into a state law status power and a community membership power. The integration between the two remains precarious.

A more recent addition is the reemergence of traditional tribal governance structures which include hereditary chiefs, nation-based councils and inter-nation confederacies. They draw on ancient governance structures but typically do not intend to replicate their historical predecessors. In this sense, they are not driven by historical revivalism, rather, they aim to step outside of the many divides created for Indigenous people by settler law including federal/provincial, status/non-status, on-reserve/off-reserve, the various categories of 'Indianness' under Section 6 of the Indian Act and so on. However, the vast majority of federal spending supporting Indigenous governance is directed to First Nations communities under the Indian Act. Thus, traditional governance organizations tend to lack the resources and institutional set-up to fully carry out political representation functions. It remains to be seen whether they will be able to muster the resources and support necessary for sustained political functioning. For present purposes, they are less relevant because they have yet to develop formal membership processes.

Thirdly, beyond the community or tribal/national level, what remains to be considered are national Aboriginal organizations and their provincial and territorial affiliates. As seen, Canada recognizes three collectivities of Indigenous Peoples: First Nations, Métis and Inuit. At the implementation level, the federal government works with three, four or five national organizations depending on the political orientation of the government of the day and/or issues at stake. The five organizations represent or seek to represent the three collectivities referenced in state law. Most of these organizations or their direct predecessors formed in the late 1960s and emerged as important players in the constitutional conferences leading up to the patriation of the Canadian Constitution in 1982. In their current iterations, these are the Assembly of First Nations (AFN), the Métis National Council (MNC), the Inuit Tapiriit Katami (ITK), the Native Women's Association of Canada (NWAC) and the Congress of Aboriginal Peoples (CAP).

The AFN's structure is closely tied to the Indian Act and its governance structures, as the key decision-making body, the Assembly, is made up of chiefs elected pursuant to the Indian Act. Its representational claim goes beyond this core constituency and includes people living off-reserve 'in cities and towns across the country'.

The MNC claims to represent the Métis. In contrast to the AFN and its broad representational claim, the representational claim of the $\mathrm{MNC}$ has been shrinking. The MNC does not now seek to represent all people of mixed Indigenous and settler descent. ${ }^{43}$ Instead, it requires that its members trace their ancestry to a single 'historic Metis Nation',

42 Indian Act, RSC 1985, c I-5 Section 10.

43 Sawchuk (2001) 19. 
which is geographically bounded in Canada's northwest. The MNC has a formal membership process that expressly references the Powley decision and seeks to meet the criteria set out there.

The ITK seeks to represent Inuit focused on 53 communities spread across the Inuvialuit Settlement Region (Northwest Territories), Nunavut, Nunavik (Northern Quebec) and Nunatsiavut (Northern Labrador). Membership processes are carried out regionally and representation by the ITK is tied to membership in one of the regional bodies.

NWAC represents Indigenous women. It does not act as a community of recognition despite representing key interests related to identity and recognition.

Finally, CAP represents off-reserve and non-status people. Membership is addressed at the provincial and territorial level through affiliates often referred to as Native Councils. It is readily apparent that CAP and NWAC have partially overlapping constituencies with the previous three organizations. Equally, it is apparent that the first three organizations do not represent all Indigenous people in Canada or, put in more constitutionally relevant terms, all people who hold rights under Section 35 of the Constitution Act, 1982, either from the perspective of Indigenous people or, indeed from the perspective of the state as expressed by Prime Minister Trudeau ${ }^{44}$ and the Supreme Court of Canada. ${ }^{45}$

From this context, a number of important issues with respect to recognition can be discerned. Firstly, recognition is at its core a relational issue. It is not an ontological claim to 'being Indigenous', rather it concerns the interface between state law and Indigenous governance as well as the interface between Indigenous governments with representational claims. It is a place where different legal and identity systems must speak to each other. Secondly, the processes and criteria must be cognizable and legitimate to the different legal systems involved, even if they do not exactly replicate each other. They must operate with mutual awareness and respect. Finally, the context of recognition is highly dynamic. Due to the various political and legal pressures that are exerted on any entity exercising jurisdiction with respect to recognition, one should expect change over time.

\section{CASE STUDY - MEMBERSHIP IN NATIVE COUNCILS}

In this regard, it seemed promising to look to the practice of Native Councils as Indigenous organizations with representational claims for historically excluded non-status and offreserve populations for guidance on issues of identity and recognition. These organizations exercising the power of recognition are constantly navigating the interface between settler law and Indigenous self-governance and must balance divergent sets of interests: recognizing the Indigeneity of individuals so recognized by their existing membership; excluding from membership those who do not meet the criteria set by the existing membership so as not to unduly dilute available rights and benefits; positioning their representational claim vis-à-vis other Indigenous organizations and maintaining a system of membership recognition that is cognizable to the settler legal order.

Membership in Native Councils is generally processed based on a written application. The criteria for granting membership may be described as Powley Plus in the sense that all Councils require evidence of Aboriginal ancestry, self-identification and community involvement and additional criteria such as residence, age and participation requirements. Challenging questions arise in the context of applications that seek recognition for new

44 Prime Minister's Office, link 2.

45 Daniels v Canada (Indian Affairs and Northern Development), [2016] 1 SCR 99, 2016 SCC. 
lines of genealogy and also in the context of cases of unknown paternity as well as custom adoption. Membership issues also sometimes arise because of changes in federal law and administration. For these reasons, membership processes continue to evolve to better reflect an evolving understanding of the relationship between ancestry, community and membership and to ensure that Councils represent non-status and off-reserve interests comprehensively.

\subsection{Ancestry}

Full membership in the New Brunswick Aboriginal Peoples Council requires evidence of an Aboriginal ancestor since July 1, 1867, the date of confederation. This date is not internally significant but signals to settler governments that the Council understands itself as an organization that navigates the boundaries between settler society and Indigenous self-governance. The same aim is expressed differently by the Nova Scotia Native Council. The NCNS expressly references the definition in Section 35 of the Constitution Act, 1982 and reserves full membership to three groups of people: status Indians (or those eligible for status); people who do not qualify for status but who can document Aboriginal ancestry and community connection; and/or are treaty rights holders. In both of these versions, the nod to settler law is readily apparent in the cut-off date (NB) and in the definitional reference (NS). The PEI Council and NunatuKavut each take a slightly different approach. NCPEI requires evidence of ancestral membership in a historic Aboriginal community. This appears to include ancestry in a community outside of PEI as the term 'Aboriginal' is defined as referring to 'the indigenous people of North America'. NunatuKavut requires evidence of 'Inuit descent [from a person] who is a member of the historic Inuit community of South/ Central Labrador.' It is apparent that there is not a single approach to addressing the ancestral connection criterion but the common thread between the organizations is that evidence of ancestral connection is required. The date cut-offs (NB) and modes of managing mobility to (PEI) and from (NunatuKavut) traditional territories speak to a nuanced understanding that is largely absent from settler legislation and jurisprudence.

\subsection{Self-identification}

All councils require that members self-identify. Again, the precise articulation of the requirement varies across councils. The most fulsome articulation comes from the NCPEI which requires:

the prospective member must self-identify as a member of an Aboriginal community; the member must hold himself or herself out and believe or consider he or she is an Aboriginal. The prospective member should be proud of his or her Aboriginal ancestry and openly identify himself or herself as being of Aboriginal ancestry.

Nova Scotia follows a similar line and requires members to:

have for a minimum of 1 year declared themselves to be and hold themselves out to be a Native Aboriginal person.

A more minimal version can be found in the by-laws of the NBAPC and NunatuKavut which merely require that each prospective member apply personally.

The variety in approaches seems to be less substantive but rather related to a varying allocation of evidence between self-identification and community acceptance. The minimal 
approach suggests that the application itself is evidence of self-identification, while the more elaborate versions are closely connected to the next criterion, community acceptance in that evidence of being 'out and proud' supports acceptance by the relevant community.

\subsection{Community Acceptance}

Community acceptance is also required by all councils but, again, there is variation in approach. In New Brunswick and Nova Scotia, the member must be accepted by the locals before an application to the Council. Applications must be endorsed by local membership clerk. This is connected to the idea that the relevant community is local. The Councils are organized in locals and zones whilst the Councils act as the organizational umbrella. NunatuKavut and NCPEI both understand themselves and act directly as the relevant communities for the purposes of community recognition.

\subsection{Additional Criteria}

The membership processes in all Councils references additional criteria for admission beyond the Powley requirements. Intriguingly, this includes the imposition of a behavioural standard for membership in some cases. For example, the by-laws of the NBAPC require a member to subscribe to the aims, goals and objectives of the Council and contemplate exclusion from membership on the basis of the contravention of specific membership offences. Similarly, the Nova Scotia rules point to Mi'kmaq/Aboriginal culture, language, tradition and ideological affinity as factors supporting an application.

\subsection{Age}

To be eligible for admission as an adult member, Native Councils in Atlantic Canada have set the minimum age at 16. This is different from federal law which sets the age of majority at 18 and provincial laws which variously set the age of majority at 18 or 19 . The younger age of majority reflects a different understanding of the political role of youth compared to settler society. While Canadian settler society tends to see teenagers as children without political voice or community obligations, Indigenous people in the Atlantic region tend to stress the importance of listening to youth as a key constituency and also actively encourage political participation. This is consistent with a strong emphasis on political work as an intergenerational undertaking. Youth representatives and youth councils are further evidence of this approach.

\subsection{Residence requirements}

All Councils require evidence of residence in the province or, in the case of Labrador, in the geographical area where they operate. Additionally, the three Maritime Councils (NBAPC, NCPEI and NCNS) require that members reside off-reserve.

\subsection{Evidentiary requirements}

All Councils require that membership applications be supported by documentary evidence. The integrity of the evidence is clearly important to the Councils. In the case of New Brunswick, all documents must either be provided in the original or certified copy. This is balanced by considerations of convenience and accessibility for members as is evident in the NunatuKavut by-laws, which contemplate a variety of formats. Evidentiary requirements 
also recognize that prospective members may require assistance in assembling the information. NBAPC in its membership handbook provides guidance on resources. Local membership clerks also provide personal assistance. The ultimate burden of demonstrating Aboriginal ancestry remains with the applicant.

The preponderance of evidentiary requirements relates to the proof of ancestry. Beyond this general observation, the approach taken to proving ancestry is again varied. For example, the NBAPC asks members to focus on one (either maternal or paternal) line, while NunatuKavut considers the entire family tree.

The design of the evidentiary requirements shows how very aware the Councils are of the difficulties created by the under-inclusive Indian Act approach. The requirements are pragmatic and augmented by basket clauses permitting alternative proof subject to Board or Assembly approval.

All Councils have fairly elaborate procedures for the admission of members including prescribed application forms, fees, prescribed timelines, documentary standards, designated staff, trained volunteers and internal appeals. These procedures afford a significant amount of procedural fairness and point to the importance of these processes to the organizations.

While most procedures will be familiar to settler jurists from administrative law procedures in settler law, there are some subtle variations. One example is the retrospective reviewability of membership in light of new or evolving criteria.

For example, the NCNS by-laws expressly preclude grand-parenting existing members if the criteria change: membership in the Association shall cease if he ceases to qualify for membership in accordance with these by-laws.

This suggests that the procedure makes room for evolving legal standards. It may also suggest that membership is not thought of as a vested right. A similar conclusion can be drawn from the NBAPC by-laws. Exclusion from membership is a remedy for a variety of membership offences.

The substantive criteria, evidentiary requirements and application procedures of Native Councils in Atlantic Canada are fully developed, align substantially with and tend to exceed the legal requirements in settler law and follow general administrative law principles of procedural fairness. They effectively address the shortcomings of under-inclusiveness and over-inclusiveness in the Indian Act regime by ensuring an appropriate balance between competing interests. Despite this, settler law recognition of Native Councils as communities of recognition has been spotty. Some courts and tribunals have recognized the membership cards of Native Councils, while others have refused to treat them as evidence of Indigeneity and/or treaty beneficiary status. ${ }^{46}$ The same is true for the political sphere. Some federal governments have treated CAP as a representative organization some of the time, others have not.

\section{CONCLUSIONS}

This article concludes with the question raised at the beginning - what is the relationship between constitutional recognition and constitutional imposition of identity? The Canadian state in its constitutional document describes itself as a liberal democracy governing a pluralist society. It also recognizes Aboriginal rights as constitutive. The first two elements have met with considerable success in terms of aligning state and citizen identity. This suggests that neutral constitutional identities or identities that respect individual diversity 
can be imposed successfully through the democratic process. The flipside of this may very well be that the imposition of majoritarian, non-neutral impositions of constitutional identities will result in constitutional alienation. The third element of constitutional recognition of Aboriginal identities as constitutive of the Canadian state has proven much more difficult. The most promising avenue for advancing constitutional recognition of Indigenous Peoples appears to lie in respecting Indigenous self-governance over the process and criteria of recognition. The Canadian experience suggests that classical liberal and pluralist modes of constitutional identity are not effective in meeting decolonizing objectives. It also casts doubt on the promise of majoritarian imposition of non-neutral constitutional identities.

\section{LITERATURE}

Albert, Richard, 'Constitutional Amendment and Dismemberment' (2018) 43 Yale J Int'l L 1-84.

Bill C-31: An Act to Amend the Indian Act (S.C. 1985, c.27).

Canadian Charter of Rights and Freedoms, Constitution Act, 1982, Schedule B to the Canada Act, 1982 c. 11 (UK).

Chartrand, Larry, 'Indigenous Peoples: Caught in a Perpetual Human Rights Prison' (2016) 67 UNBLJ $167-86$.

Coulthard, Glen, 'Subjects of Empire: Indigenous Peoples and the 'Politics of Recognition in Canada' (2007) 6 Contemporary Political Theory 437-60.

Daniels v Canada (Indian Affairs and Northern Development), [2016] 1 SCR 99, 2016 SCC 12.

de Costa, Ravi, 'Descent, Culture, and Self-Determination: States and the Definition of Indigenous Peoples' (2014) 3 Aboriginal Policy Studies 55-85.

Descheneaux v. Canada (AG), 2015 QCCS 3555.

Gardiner-Garden, John, 'Defining Aboriginality in Australia' (2003) 10:2002-03 Current Issues Brief 1. 1-32.

Gehl v Canada (Attorney General), 2017 ONCA 319.

Grammond, Sébastien, Identity Captured by Law: Membership in Canada's Indigenous Peoples and Linguistic Minorities (McGill-Queens's University Press 2009).

Grammond, Sebastien - Groulx, Lynne, “Finding” Metis Communities' (2012) 32 Canadian Journal of Native Studies 33-48.

Green, Joyce, 'Canaries in the Mines of Citizenship: Indian Women in Canada' (2001) 34 Canadian Journal of Political Science/Revue canadienne de science politique 715-38.

Green, Joyce, 'The Impossibility of Citizenship Liberation for Indigenous People' in Mann, Jatinder (ed) Citizenship in Transnational Perspective, (Cham: Springer, 2017) 175-88.

Hirschl, Ran, 'Opting Out of "Global Constitutionalism"” (2018) 12 Law \& Ethics of Human Rights $1-36$.

Hughes, Jula and Stewart, Roy, 'Urban Aboriginal People and the Honour of the Crown - A Discussion Paper' (2015) 66 UNBLJ 263-99.

Hughes, Jula - Stewart, Roy - Plummer, Anthea, 'Non-Status and Off-Reserve Aboriginal Representation in New Brunswick: Speaking for Treaty and Claims Beneficiaries' (UAKN 2015).

MacKenzie, David, 'The Indian Act and the Aboriginal Peoples of Newfoundland at the Time of Confederation' (2010) 25 Newfoundland and Labrador Studies 1719-26.

McNeil, Kent, 'The Constitutional Rights of the Aboriginal Peoples of Canada' (1982) 4 SCLR 25565.

Napoleon, Val, 'Aboriginal Discourse: Gender, Identity, and Community' in Richardson, Benjamin, Imai, Shin and McNeil, Kent (eds) Indigenous Peoples and the Law: Comparative and Critical Perspectives (Hart Publishing 2009) 233-55.

O'Byrne, Nicole, 'A Rather Vexed Question...: The Federal-Provincial Debate over the Constitutional Responsibility for Métis Scrip' (2006) 12 Rev Const Stud 215-53.

Patterson, Lisa Lynne, 'Aboriginal Roundtable to Kelowna Accord: Aboriginal Policy Negotiations, 2004-2005' PRB 06-04E (Ottawa: Parliamentary Information and Research Service Ottawa, 2006). 
R v Blais, [2003] 2 SCR 236, 2003 SCC.

Reference re Refunds of Dues re Timbre Permits, [1933] SCR 616, aff'd In re Refund of Dues Paid Under s. 4769 of the Timber Regulations in Manitoba, British Columbia, Saskatchewan and Alberta, [1935] AC 184 (PC).

Rosenfeld, Michel, The Identity of the Constitutional Subject: Selfhood, Citizenship, Culture, and Community (London: Routledge 2009).

Sandra Lovelace v Canada, Communication No. 24/1977: Canada 30/07/81.

Sawchuk, Joe, 'Negotiating an Identity: Métis Political Organizations, the Canadian Government, and Competing Concepts of Aboriginality' (2001) 25 American Indian Quarterly 73-92.

Sayers, Judith et al., 'First Nations Women, Governance and the Indian Act: A Collection of Policy Research Reports' (Ottawa: Status of Women Canada, 2001).

\section{LINKS}

1. Cossette, Marc-André, “Déjà vu” for First Nations women, as Ottawa seeks more time to rid Indian Act of sexism | CBC News', (12 June 2017), online: $c b c c a<\mathrm{http} / /$ www.cbc.ca/news/ politics/indian-act-gender-discrimination-deja-vu-1.4153483> accessed 5 May 2018.

2. Prime Minister's Office, Statement by the Prime Minister of Canada on meeting with National Aboriginal Organizations, (2015) <pm.gc.ca/eng/news/2015/12/16/statement-prime-ministercanada-meeting-national-aboriginal-organizations.> accessed 5 May 2018.

3. Thomson, Aly 'About 80,000 denied eligibility for Newfoundland first nation band' (2017) Globe and Mail, online: <https://www.theglobeandmail.com/news/national/only-18000-eligible-fornewfoundland-first-nation-band-its-discriminatory/article33925034/>, accessed 5 May 2018. 